\title{
Pengaruh Bauran Promosi Terhadap Peningkatan Jumlah Tamu pada Wisma Graha Az-Zahra Pekanbaru
}

\author{
ZULKIFLI RUSBY* \\ BOY SYAMSUL BAKHRI** \\ SYAHRUL ROZI ${ }^{* * *}$
}

\begin{abstract}
* Fakultas Agama Islam (FAI) Universitas Islam Riau (UIR) Jl. Kaharuddin Nasution, No.113, Perhentian Marpoyan Pekanbaru 28284, Email: zulkiflirusby@yahoo.com

**Fakultas Agama Islam (FAI) Universitas Islam Riau (UIR), Jl. Kaharuddin Nasution No. 113,Perhentian Marpoyan, Pekanbaru 28284 e-mail: bsb bm@yahoo.co.id

***Fakultas Agama Islam (FAI) Universitas Islam Riau (UIR), Jl. Kaharuddin Nasution No. 113,Perhentian Marpoyan, Pekanbaru 28284
\end{abstract}

\begin{abstract}
Abstrak: Penelitian ini dilatarbelakangi oleh Wisma Syariah Graha Az-Zahra Pekanbaru mengalami permasalahan terhadap jumlah tamu yang mengalami penurunan. Hal ini diduga terjadi karena belum optimalnya perusahaan dalam mempromosikan produk-produknya kepada masyarakat/pelanggan/tamu. Adapun yang menjadi perumusan masalah dalam penelitian ini adalah bagaimana pengaruh bauran promosi terhadap peningkatan jumlah tamu pada Wisma Syariah Graha Az-Zahra Pekanbaru. Tujuan penelitian ini adalah untuk mengetahui pengaruh bauran promosi terhadap peningkatan jumlah tamu. Subjek penelitian ini adalah tamu yang menggunakan jasa penginapan. Sementara objek dalam penelitian ini adalah pengaruh bauran promosi terhadap peningkatan jumlah tamu. Sumber data yang digunakan dalam penelitian ini data primer dan data sekunder. Teknik pengambilan sampel digunakan dengan cara simple random sampling, sedangkan teknik pengumpulan data yang digunakan adalah angket atau kuesioner dan dokumentasi. Untuk menganalisis data digunakan metode deskriptif kuantitatif. Dalam menganalisis data kuantitatif digunakan analisis regresi linear sederhana dimana proses perhitungannya menggunakan SPSS for windows versi 17.0. Hasil penelitian ini diketahui bauran promosi terhadap peningkatan jumlah tamu memiliki hubungan yang kuat, ini diketahui dari nilai koefisien korelasi sebesar 78,1\%. Sedangkan hasil uji parsial terdapat pengaruh yang signifikan antara bauran promosi terhadap peningkatan jumlah tamu, ini diketahui dari t hitung sebesar 12,176. Kemudian terdapat besarnya kontribusi antara bauran promosi terhadap peningkatan jumlah tamu, diketahui dengan nilai koefisien determinasi sebesar $60,9 \%$. Secara umum dapat disimpulkan bahwa bauran promosi terhadap peningkatan jumlah tamu pada Wisma Syariah Graha Az-Zahra Pekanbaru sangat berpengaruh.
\end{abstract}

Kata kunci: Bauran Promosi, Peningkatan Jumlah Tamu, Wisma Syariah. 



\section{PENDAHULUAN}

Perkembangan dunia usaha dan persaingan bisnis yang semakin ketat dan kompetitif, menuntut dan menyadarkan para pelaku bisnis untuk mampu bersaing. Sistem persaingan tersebut dapat mempengaruhi perkembangan atau tidaknya suatu bisnis, salah satunya yang bergerak di bidang jasa penginapan. Peluang bisnis jasa penginapan di Riau dan Kota Pekanbaru pada khususnya masih terbuka lebar untuk semua pelaku bisnis. Semakin pesatnya dan berkembangnya Kota Pekanbaru memungkinkan banyaknya pengunjung terutama para pelaku bisnis yang memerlukan tempat peristirahatan. Apalagi didukung dengan tingkat perekonomian masyarakat Riau yang cukup baik, hal tersebut menjadi dasar pengembangan bisnis jasa penginapan di Riau. Bahkan, di kota Pekanbaru telah banyak berdirinya beberapa tempat yang menyediakan jasa penginapan.

Seiring dengan inovasi yang terus diupayakan pada bisnis jasa penginapan, bisa kita temui dilapangan fasilitasfasilitas dan produk-produk yang berkualitas yang disajikan meliputi pelayanan dan konsep serta sistem yang memegang prinsip-prinsip syariah. Upaya ini dilakukan guna memberikan suasana tentram, nyaman, sehat dan bersahabat. Semua itu tidak lain hanya untuk menarik minat pelanggan atau konsumen agar mau menginap di jasa penginapan yang mereka tawarkan.

Namun upaya tersebut tidak menjamin untuk meraih tujuan perusahaan yang tepat sasaran dalam memberi kepuasan konsumen secara lebih efesien dan efektif. Hal yang perlu dipikirkan oleh perusahaan adalah harus mampu untuk menghadapi para pesaing dan perusahaan sejenis yang semakin banyak bermunculan, perusahaan harus mampu bertahan dan berkembang dalam menghadapi persaingan usaha dalam jangka panjang.

Manajemen perusahaan harus mampu menyusun program pemasaran yang baik guna menarik perhatian dan kepercayaan pelanggan atau konsumen agar bersedia menggunakan produkproduk dan jasa yang mereka butuhkan. Oleh karena itu, kegiatan pemasaran mempunyai peranan yang sangat penting untuk menginformasikan produk-produk yang ditawarkan tersebut agar dapat meningkatkan jumlah tamu.

Upaya terpenting dalam manajemen perusahaan yang harus lakukan adalah melakukan strategi pemasaran yang tepat, dalam bukunya New Consumer Marketing, Susan Baker menerangkan bahwa dalam era ekonomi konsumsi seperti saat ini, menggunakan $4 \mathrm{P}$ atau marketing mix (bauran pemasaran) yaitu produk (product), harga (price), tempat/ distribusi (place) dan promosi (promotion), sebagai basis strategi pemasaran (Kartajaya dan Sula, 2008: 157).

Salah satu bauran pemasaran atau faktor utama dalam bauran pemasaran adalah promosi. Promosi merupakan kegiatan perusahaan dalam usahanya untuk berkomunikasi dengan konsumen, strategi dan penerapan promosi yang tepat merupakan salah satu cara untuk mengkomunikasikan produk kepada konsumen. Pemilihan bentuk promosi setiap perusahaan berbeda-beda tergantung pada karakteristik produk dan kebijakan pemasaran yang dilaksanakan. Penyampaian informasi lewat promosi dapat merubah dan mempengaruhi pengetahuan, perasaan, dan sikap pelanggan atau konsumen dalam membuat keputusan penggunaan suatu produk atau jasa.

Sayangnya, penerapan promosi pemasaran tidak semudah yang direncanakan, ada kalanya tidak tepat 
sasaran dan hasilnya kurang optimal. Hal ini disebabkan kurang tepatnya pemilihan media sehingga terjadi pemborosan sehingga visi dan misi utama perusahaan untuk memperkenalkan produknya manjadi gagal.

Wisma Syariah Graha Az-Zahra merupakan salah satu bisnis jasa penginapan yang ada di Riau Kota Pekanbaru. Konsep awal berdirinya Wisma Syariah Graha Az-Zahra yakni untuk menumbuhkan citra Kota Pekanbaru sebagai kota dengan label Metropolis kedepannya, tapi masih dapat memberikan kesempatan kepada strata menengah kebawah untuk menikmati keindahan Kota Pekanbaru. Maka pada tanggal 01 Agustus tahun 2008, dioperasikanlah Wisma Syariah Graha Az-Zahra yang berlokasi di jalan Rindang No 16 B, Bukit Raya Pekanbaru. Wisma Syariah Graha Az-Zahra menawarkan tempat peristirahatan, dengan menyediakan fasilitas kamar tidur, makanan, dan minuman baik bagi anda yang sedang melaksanakan bisnis maupun rekreasi, dengan mengedepankan prinsip-prinsip syariah atau pedoman ajaran Islam, guna memberikan suasana tenteram, nyaman, sehat dan bersahabat yang dibutuhkan oleh konsumen/tamu.

Dilihat dari banyaknya bisnis jasa penginapan dengan berbagai produk dan jasanya maka hal ini akan memunculkan persaingan diantara jasa penginapan. Untuk memenangkan persaingan tersebut, Wisma Syariah Graha Az-Zahra senantiasa melaksanakan berbagai kegiatan promosi terhadapa produk-produknya. Berdasarkan tinjauan yang telah penulis lakukan, diperolehlah data yang diberikan oleh Ibu Sy Artina Wika Sari, selaku manajer di Wisma Syariah Graha Az-Zahra Pekanbaru, yang meliputi berbagai bentuk promosi yaitu: (1) Periklanan (advertensi); dan (2) Promosi (promotion).

Menurut teori pemasaran, sasaran promosi dapat tercapai apabila perusahaan menganggarkan biaya promosi yang memadai dan dengan adanya biaya promosi yang memadai diharapkan dapat membantu perusahaan dalam memasarkan produknya. Namun sayangnya, promosi yang dilakukan perusahaan Wisma Syariah Graha Az-Zahra untuk meningkatkan jumlah tamu menginap berdampak negatif hal ini terlihat selama periode tahun 2014 - 2016 jumlah tamu dari tahun ke tahun mengalami fluktuasi. Hal tersebut dapat dilihat pada tabel jumlah tamu menginap dari tahun ke tahun selama periode Tahun 2014 - 2016 di bawah ini:

Tabel 1: Jumlah tamu yang menginap di Wisma Syariah Graha Az-Zahra Pekanbaru selama Periode Tahun 2014 - 2016

\begin{tabular}{ccc}
\hline NO & Tahun & JUMLAH TAMU \\
\hline 1. & 2014 & $\mathbf{5 . 2 1 8}$ \\
\hline 2. & 2015 & $\mathbf{5 . 0 6 1}$ \\
\hline 3. & 2016 & $\mathbf{3 . 4 4 8}$ \\
\hline
\end{tabular}

Berdasarkan data diatas dapat diketahui jumlah tamu yang menginap di Wisma Syariah Graha Az-Zahra Pekanbaru selama periode tahun 2014 sampai dengan tahun 2016 menunjukkan adanya penurunan jumlah tamu yang menginap. Hal ini dapat dilihat selama tahun 2014 jumlah tamu menginap dari 5.218 orang atau sebesar 43,4\% menurun menjadi 5.061 orang atau sebesar $42,1 \%$ pada tahun 2015. Dan mengalami penurunan lagi dari 5.061 orangatau sebesar $42,1 \%$ pada tahun 2015, menjadi 3.448 orangatau sebesar $28,7 \%$ pada tahun 2016. Hal ini diduga terjadi karena kurangnya Vol. 14, No. 2, Oktober 2017 
strategi pemasaran dalam mempromosikan produk Wisma kepada masyarakat atau konsumen/tamu. Hal ini harusnya menjadi pelajaran bagi perusahaan untuk mengkaji agar peningkatan jumlah tamu menginap terus tercapai sesuai target yang di tetapkan, misalnya dengan meningkatkan kegiatan promosi yang dilakukan.

Berdasarkan keterangan dan penjelasan tersebut diatas, maka penulis tertarik untuk mengkaji dan mempelajari tentang pengaruh bauran promosi dalam meningkatkan jumlah tamu menginap pada perusahaan yang dikelola oleh Wisma Syariah Graha AzZahra Pekanbaru. Oleh karena itu penulis mengangkat persoalan ini dalam bentuk penelitian dengan judul " Pengaruh Bauran Promosi Terhadap Peningkatan Jumlah Tamu Pada Wisma Syariah Graha Az-Zahra Pekanbaru".

Adapun yang menjadi perumusan masalah dalam penelitian ini adalah bagaimana pengaruh bauran promosi terhadap peningkatan jumlah tamu pada Wisma Syariah Graha Az-Zahra Pekanbaru? Sedangkan yang menjadi tujuan penelitian ini adalah untuk mengetahui pengaruh bauran promosi terhadap peningkatan jumlah tamu pada Wisma Syariah Graha Az-Zahra Pekanbaru. Adapun kegunaan penelitian ini adalah sebagai berikut: (1) Hasil penelitian ini dapat dijadikan bahan masukan bagi Wisma Syariah Graha AzZahra Pekanbaru dalam menentukan promosi atau pemasaran produk untuk meningkatkan jumlah tamu; dan (2) Sebagai bahan kajian ilmiah dan menambah referensi dunia pengetahuan dalam mengembangkan kemampuan berpikir dan menganalisa suatu permasalahan serta menerapkan segala ilmu yang telah di peroleh.

\section{Hakikat Promosi}

Dalam Kamus Besar Bahasa Indonesia (KBBI), pengertian promosi berasal dari kata Pro.mo.si, artinya kenaikan pangkat (tingkat); naik pangkat (tingkat); perkenalan (dalam rangka memajukan usaha, dagang, dan sebagainya). (Departemen Pendidikan Nasional RI, 2008: 1105).

Menurut Enis dan Stanton menyimpulkan bahwa promosi itu adalah sejenis komunikasi yang memberi penjelasan yang meyakinkan calon konsumen tentang barang dan jasa (Manap, 2016: 301). Sedangkan menurut Bumet, Promosi ialah merupakan aktivitas marketing untuk mengkomunikasikan informasi tentang perusahaan dan produknya kepada konsumen, sehingga menciptakan permintaan. (Adam, 2015: 33).

Kemudian menurut Zimmerer, promosi adalah segala macam bentuk komunikasi persuasi yang dirancang untuk menginformasikan pelanggan tentang produk atau jasa dan untuk memengaruhi mereka agar membeli barang atau jasa tersebut yang mencakup publisitas, penjualan perorangan dan periklanan (Rangkuti, 2009: 50).

Berdasarkan beberapa pendapat para ahli tersebut dapat diketahui bahwa promosi merupakan salah satu dari variabel marketing mix yang sangat penting dalam manajemen pemasaran. Promosi merupakan rangkaian usaha untuk menarik perhatian konsumen melalui informasi yang diberikan kepada konsumen untuk memberitahukan adanya produk baru perusahaan. Promosi merupakan penyampaian informasi dari penjual kepada pembeli untuk mempengaruhi sikap dan tingkah laku dalam rangka menciptakan pertukaran, sehingga tujuan untuk meningkatkan kuantitas jumlah diharapkan dapat terealisasi.

\section{KONSEP TEORI}




\section{Tujuan Promosi}

Tujuan utama promosi ialah memberi informasi, menarik perhatian dan selanjutnya memberi pengaruh meningkatnya penjualan. Menurut Schoen, tujuan promosi ialah memperoleh perhatian, mendidik, mengingatkan, meyakinkan. (Manap, 2016: 303).

Promosi melaksanakan satu dari tiga tugas yaitu: (1) Informing (menginformasikan). Informasi yang informatif berusaha mengubah kebutuhan yang sudah ada menjadi keinginan atau memberi stimulasi minat pada sebuah produk baru. Hal ini terutama terjadi pada tahap dini dari daur hidup sebuah produk. Orang secara khas tidak akan membeli sebuah produk atau jasa atau mendukung sebuah organisasi nirlaba sebelum diketahui maksud dan keuntungannya bagi mereka;(2) Persuading (membujuk). Promosi dibuat dengan cara membujuk orang untuk masuk menggunakan produk atau jasa. Persuasi biasanya menjadi tujuan promosi utama bila produk memasuki tahap pertumbuhan dari daur produknya. Pada saat itu, pasar tertuju (target market) sudah harus mempunyai kesadaran atau pengetahuan akan produk tersebut mengenai cara memenuhi keinginannya. Dengan demikian, tugas promosi berubah dari menginfor-masikan kepada konsumen menjadi membujuk konsumen untuk membeli produk merek tertentu, bukan membeli merek pesaing. Pada saat itu, berita promosi menekankan keunggulan yang sesungguhnya atau apa yang dipersepsikan tentang produk tersebut. Hal tersebut dilakukan secara baik dengan memenuhi kebutuhan emosional konsumen, seperti kecintaan terhadap produk, harga diri dan kepuasaan egonya; dan (3) Reminding (mengingatkan). Promosi digunakan juga untuk mempertahankan merek dalam benak orang. Bentuk promosi ini terutama dilakukan pada tahap kedewasaan daur hidup produk. Asumsinya adalah pasar tujuan telah diyakinkan mengenai kebaikan barang atau jasa yang ditawarkan. Tujuannnya untuk mengingatkan kembali keberadaan produk tersebut di tengah pasar. (Setiyaningrum, et al.2015: 225226).

\section{Keuntungan dan Kerugian Promosi}

Adapun keuntungan promosi bagi konsumen dan produsen, yaitu: (a) Bagi konsumen keuntungannya adalah dapat mengatur pengeluarannya menjadi lebih baik, misalnya konsumen yang membaca iklan, dapat membeli barang yang lebih murah. Dengan dipasangnya iklan disurat kabar, majalah dan sebagainya, maka harga surat kabar tersebut bisa terjangkau oleh masyarakat umum. Jika surat kabar tidak ada penghasilan dari pemasangan iklan, maka harga surat kabar tersebut akan mahal; (b) Bagi produsen keuntungannya adalah promosi dapat menghindarkan persaingan berdasrkan harga, karena konsumen membeli barang karena tertarik akan mereknya. Promosi menimbulkan goodwill terhadap merek. Promosi bukan saja meningkatkan penjualan tapi juga dapat menstabilkan produksi; dan (c) Keuntungan selanjutnya ialah produsen dengan goodwill yang besar akan dapat memperoleh modal dengan murah.

Sedangkan kerugian promosi bagi konsumen dan produsen, yaitu: (a) Bagi konsumen kerugiannya adalah dibujuk untuk membeli barang yang kadangkadang barang tersebut belum dibutuhkannya, atau belum waktunya dimilki; (b) Bagi produsen kerugiannya adalah konsumen mengharapkan barang-barang yang diproduksi oleh pabrik mempunyai uniformitas, artinya 
mutunya selalu baik dan harga stabil sesuai dengan promosi yang dilancarkan, tetapi kadang-kadang hal ini tidak dapat dipenuhi; dan (c) Kerugian selanjutya bagi produsen ialah apabila perusahaan sudah mulai dengan usaha promosi, maka usaha tersebut harus dilakukan terus-menerus, ini menyebabkan biaya promosi akan selalu ada bahkan meningkat pula. (Manap,2016: 303).

\section{Konsep Bauran Promosi}

Untuk dapat mengkonsumsi produknya dengan efektif, perusahaan harus menentukan terlebih dahulu target marketnya dan kemudian mengkombinasikan promotion tools (alat-alat promosi), yaitu advertising, sales promotion, public relation, direct marketing, dan personal selling sedemikian rupa sehingga konsumen dapat mengenal produk perusahaan dan tertarik untuk membeli produk tersebut. Elemen-elemen promosi dari bauran pemasaran jasa tersebut merupakan alat yang penting dalam membantu mengkomunikasikan penempatan jasa terhadap pelanggan dan pasar yang terkait.

Menurut Nickels, bauran promosi meliputi tujuh saluran: Periklanan (adversiting), Penjualan Personal (personal selling), Promosi Penjualan (sales promotion), Hubungan Masyarakat (public relations), Komunikasi Dari Mulut Ke Mulut (word of mounth), Pemasaran Langsung (direct marketing) dan Pemasaran Melalui Internet (internet marketing). (Agus Hermawan, 2012: 54).

Untuk memahami lebih dalam tentang bauran promosi akan dijelaskan di bawah ini: (1) Periklanan (adversiting). Periklanan memegang peranan yang cukup penting dan merupakan bagian dari kehidupan industri modern, dan umumnya hanya bisa ditemukan di negara-negara maju atau negara-negara yang tengah berkembang. Kebutuhan akan adanya periklanan berkembang seiring dengan pertumbuhan penduduk dan kota-kota yang dipenuhi oleh banyak toko, restoran dan pusat-pusat perdagangan serta penyedia jasa. Selain itu perkembangan periklanan juga sangat dipengaruhi dengan perkembangan media baik media cetak maupun media elektronik; (2) Penjualan Personal (personal selling). Penjualan personal adalah komunikasi langsung antara penjual dan calon pelanggan untuk memperkenalkan suatu produk kepada calon pelanggan dan membentuk pemahaman pelanggan terhadap produk sehingga mereka kemudian akan mencoba dan membelinya. Nilai unit yang tinggi, keperluan akan menjelaskan produk, karakteristik produk yang kompleks, detail barang yang perlu penjelasan merupakan sebagian karakteristik tenaga penjual pun akan banyak didiskusikan. Karena di tangan penjuallah terletak kunci keberhasilan dari komunikasi pemasaran penjualan langsung. Kompensasi yang pantas dan strategi pendekatan kepada calon pembeli yang memiliki prospek merupakan hal yang harus dikuasai wiraniaga; (3) Promosi Penjualan (sales promotion). Promosi penjualan merupakan aktivitas pemasaran yang mengusulkan nilai tambah dari suatu produk dalam jangka waktu tertentu dalam rangka mendorong pembeliian konsumen, efektivitas penjualan, atau mendorong upaya yang dilakukan oleh tenaga penjualan (sales force). Dari pengertian tersebut, promosi penjualan yang ditawarkan memungkinkan konsumen untuk memiliki kesempatan mendapatkan lebih dari apa yang mereka pikirkan menyangkut nilai barang. Dengan mengintegrasikan antara kemampuan tenaga penjual, iklan dan dukungan promosi penjualan, 
promosi yang dilakukan penjual akan menjadi daya tarik yang dapat mempercepat terjadinya proses pembelian; (4) Hubungan Masyarakat (public relations). Hubungan masyarakat merupakan upaya komunikasi menyeluruh dari suatu perusahaan untuk memengaruhi persepsi, opini, keyakinan dan sikap berbagai kelompok terhadap perusahaan tersebut. Kelompok-kelompok yang dimaksud di sini adalah mereka yang terlibat, mempunyai kepentingan dan dapat memengaruhi kemampuan perusahaan dalam mencapai tujuan. Kelompokkelompok tersebut bisa terdiri dari karyawan dan keluarganya, pemegang saham, pelanggan, khalayak/orangorang yang tinggal di sekitar organisasi, pemasok, perantara, pemerntah, serta media massa. Kegiatan-kegiatan yang dilakukan dalam hubungan masyarakat diantaranya: (a) Hubungan Komunitas, secara komprehensif hubungan masyarakat melalui program berkelanjutan (sustainability program) bagi warga masyarakat untuk mendapat citra positif dan meletakkan organisasi sebagai pihak yang peduli terhadap komunitas masyarakat di mana perusahaan berada; dan (b) Hubungan Masyarakat dan Kepentingan Umum, perusahaan berusaha menghasilkan citra positif dan memosisikan diri sebagai warga negara yang bertanggung jawab melalui penerapan berbagai program yang dilakukan untuk kepentingan umum, mencakup program identitas perusahaan seperti perubahan nama dan merek dagang baru untuk mengubah citra dan identitas perusahaan. Seperti ulang tahun, pameran dagang, pameran khusus, festival dan acara lainnya; (5)Komunikasi Dari Mulut Ke Mulut (word of mounth). People dalam jasa ini adalah orang-orang yang terlibat langsung dalam menjalankan segala aktivitas perusahaan dan merupakan faktor yang memegang peranan penting bagi semua organisasi. Dalam perusahaan jasa unsur People ini bukan hanya memainkan peranan penting dalam bidang produksi atau operasional saja, tetapi juga dalam melakukan hubungan kontak langsung dengan konsumen; (6) Pemasaran Langsung (direct marketing). Adalah pendekatan pemasaran yang bersifat bebas dalam menggunakan saluran distribusi dan/atau komunikasi pemasaran, yang memungkinkan perusahaan memiliki strategi tersendiri dalam berhubungan dengan konsumen. Tidak ada perantara dalam pemasaran langsung. Maka "langsung" di sini berarti dilakukan secara langsung antara perusahaan dan konsumen. Terdapat sejumlah media pemasaran langsung selain surat langsung meliputi: (a) Brosur, merupakan pendekatan yang dilakukan langsung ke calon konsumen. Brosur biasanya disebarkan langsung ke rumah-rumah atau disebarkan pada saat acara atau pameran; dan (b) Telepon, pemasaran langsung berbasis telepon dapat berupa inbound dan outbond. Inbound telemarketing (telemarketing ke dalam) dikenal sebagai pelayanan jarak jauh dan biasanya melibatkan penanganan pesanan dan merespon permintaan informasi produk. Outbound telemarketing (telemarketing ke luar) digunakan sebagai penjualan satu langkah (one-step selling), tindak lanjut dan penjualan, memperbesar dan membuat pelanggan jadi aktif; dan (7) Pemasaran Melalui Internet (internet marketing). Pemasaran melalui Internet sebenarnya sederhana dalam makna namun kompleks dalam implementasinya. Dengan Internet pemasaran produk dapat lebih terbantu, karena Internet memungkinkan proses pemasaran yang lebih efektif, respon yang lebih cepat dan biaya yang lebih murah. Basis utama pemasar dalam pemasaran Internet adalah dengan 
menggunakan dan memanfaatkan website. Proses dimana suatu prusahaan menggunakan Internet untuk mencari dan membina hubungan, yang akan digunakan untuk keuntungan di dunia nyata. Pemasaran Internet lokal menggunakan perangkat yaitu media sosial dalam memasarkan produkproduknya (Hermawan, 2012: 71- 212).

\section{Konsep Peningkatan Jumlah Tamu}

Dalam Kamus Besar Bahasa Indonesia (KBBI). Pengertian dari peningkatan adalah proses, cara, perbuatan meningkatkan (usaha, kegiatan, dan sebagainya). (Departemen Pendidikan Nasional RI, 2008: 1470).

Dari pengertian di atas dapat digabungkan pengertian dari peningkatan jumlah tamu merupakan proses, cara atau usaha sebuah perusahaan dalam upaya meningkatkan jumlah pelanggan/tamu untuk menginap setiap tahun melalui bauran promosi.

Keberhasilan usaha jasa penginapan dari waktu ke waktu tentunya harus terus dinilai atau dievaluasi, terutama berkaitan dengan posisi jasa penginapan di pasar terutama posisi bersaingnya. Posisi bersaing dalam rangka keberhasilan usaha jasa penginapan harus dapat ditingkatkan dan dipertahankan, sehingga menjadi keberhasilan usaha yang berkelanjutan, dan mencapai ujuan utama didirikannya perusahaan yaitu mendapatkan keuntungan dan mempertahankan laba.

Suatu hal yang perlu mendapat perhatian dalam menentukan sasaran atau target untuk meningkatan jumlah tamu di jasa penginapan diantaranya yaitu: (a) Berkaitan dengan hunian kamar hotel (room occupancy), yakni mengetahui banyaknya tingkat hunian kamar yang dihuni/dipakai oleh tamu. Dengan cara menghitung jumlah kamar yang terpakai dibagi dengan jumlah kamar yang tersedia dikalikan dengan $100 \%$, yang mana tujuannya adalah untuk mengetahui: (1) Tingkat hunian kamar hotel (room occupancy rate); (2) Tingkat hunian tempat tidur (bed occupancy rate); dan (3) Rata-rata lama tamu menginap (lenght of stay)(Oka A. Yoeti, 2007: 87); dan (b) Loyalitas pelanggan (customer loyalty). Griffin menyatakan bahwa Loyalty is defined as non-random purchase expressed over time by some decision-making unit. Karakteristik dari loyalitas ini ialah konsumen melakukan pembelian ulang secara teratur/reguler. Mereka juga membeli produk-produk lain bukan satu produk saja yang ditawarkan oleh produsen, mereka merekomendasi teman-temannya untuk juga membeli produk yang sama ke tempat yang sama, dan mereka tidak mudah beralih ke produk saingan.

Bagi sebuah perusahaan jasa bukan mempertahankan customer yang sudah ada saja perlu diperhatiakan, tetapi yang lebih penting lagi ialah bagaimana mereka menjadi loyalisloyalis, yaitu orang yang membela nama baik, dan menyebarkan nilai-nilai positif lembaga ke dunia luar. Adalah keberhasilan tim marketing yang luar biasa, jika perusahaan dapat memupuk customer loyalty. Jika perusahaan jasa secara konsisten memperhatikan kepentingan konsumen atau pelanggan maka konsumen atau pelanggan akan tetap berlangganan dengan perusahaan dan menjaga relationshipnya. (Manap, 2016: $374-376)$.

\section{Konsep Dasar Wisma Syariah}

Dalam Kamus Besar Bahasa Indonesia (KBBI). Definisi dari Wisma adalah sebagaiNomina (kata benda). Bangunan untuk tempat tinggal, kantor, dan sebagainya; atau gerha; kumpulan rumah; kompleks perumahan; 
permukiman. (Departemen Pendidikan Nasional, 2008: 1563).

Seperti yang sudah diketahui wisma merupakan suatu usaha yang menyediakan jasa bagi anda yang memerlukan salah satu tempat peristirahatan, dengan menyediakan fasilitas kamar tidur, makanan, dan minuman baik yang sedang melaksanakan bisnis maupun rekreasi.

Dalam Kamus Besar Bahasa Indonesia (KBBI), Syariah atau Syariat adalah hukum agama yang menetapkan peraturan hidup manusia, hubungan manusia dengan Allah Subhanahu Wa Ta'ala, hubungan manusia dengan manusia dan alam sekitar berdasarkan Al-Quran dan Hadits. (Departemen Pendidikan Nasional, 2008: 1368).

Dari pengertian Wisma dan Syariah di atas, maka dapat digabungkan pengertian dari Wisma Syariah, adalah sebuah tempat yang berfungsi menyediakan jasa bagi anda yang memerlukan salah satu tempat peristirahatan, sebagaimana lazimnya yang operasional dan layanannya telah menyesuaikan dengan hukum agama prinsip-prinsip syariah atau pedoman ajaran islam, guna memberikan suasana tenteram, nyaman, sehat dan bersahabat yang dibutuhkan oleh konsumen/tamu.

Selanjutnya, untuk menghindari kesalahfahaman judul skripsi ini ada baiknya penulis sajikan penilitian yang relevan dengan penelitian yang penulis lakukan ini adalah:

Tugas akhir yang dilakukan oleh Dewi Kusuma Wardhani tahun 2016 dengan judul, Pengaruh Jasa Hotel Rauda Terhadap Keputusan Tamu Menginap Pada Hotel Rauda Pekanbaru. Hasil penelitian ini bertujuan untuk mengetahui signifikansi pengaruh jasa hotel Rauda terhadap keputusan tamu menginap di hotel Rauda Pekanbaru. Perbedaan penelitian dengan penulis lakukan yaitu terdapat dalam penelitian ini dari variabel bebas dan variabel terikatnya serta tempat penelitian yang berbeda, sedangkan persamaan dengan penulis diantaranya teknik pengumpulan data dengan kuesioner.

Tugas akhir yang dilakukan oleh Dani Rahadian Adithya Pratomo tahun 2013 dengan judul, Pengaruh Bauran Promosi Terhadap Peningkatan Penjualan Kamar Di Hotel Benua Bandung. Hasil penelitian ini bertujuan untuk mengetahui signifikansi pengaruh simultan bauran promosi (periklanan, penjualan pribadi, dan promosi penjualan), terhadap peningkatan penjualan kamar di hotel Benua Bandung. Perbedaan penelitian dengan penulis lakukan yaitu terdapat dalam penelitian ini dari variabel bebas dan variabel terikatnya serta tempat penelitian yang berbeda, sedangkan persamaan dengan penulis teknik pengumpulan data diantaranya dengan dokumentasi.

Adapun variabel penelitian ini terdiri dari variabel independen dan variabel dependen. Variabel independen atau variabel bebas $(\mathrm{X})$ adalah variabel yang mempengaruhi atau yang menjadi sebab perubahannya atau timbulnya variabel terikat, adapun variabel bebas dalam penelitian ini yaitu bauran promosi. Variabel dependen atau variabel terikat (Y) adalah variabel yang dipengaruhi atau yang menjadi akibat karena adanya variabel bebas, adapun variabel terikatdalam penelitian ini yaitu peningkatan jumlah tamu.

\section{METODE}

Desain yang dilakukan dalam penelitian ini yaitu desain penelitian kausalitas. Desain penelitian kausalitas adalah jenis penelitian yang disusun untuk meneliti kemungkinan adanya hubungan sebab-akibat antarvariabel, sehingga peneliti dapat menyatakan klasifikasi variabel-variabelnya. Dalam jenis penelitian ini, umumnya hubungan 
sebab-akibat sudah dapat diprediksi oleh peneliti, sehingga peneliti dapat menyatakan klasifikasi variabel bebas, dan variabel terikat (Sanusi, 2011: 14).

Adapun tempat penelitian ini dilakukan di Wisma Syariah Graha AzZahra. Yang beralamat jalan Rindang No. 16 B. Bukit Raya Pekanbaru-Riau. Sedangkan waktu penelitian ini dilakukan pada bulan Januari sampai dengan bulan April 2017 .

Populasi adalah seluruh elemen yang menunjukkan ciri-ciri tertentu yang dapat digunakan untuk membuat kesimpulan. Jadi, kumpulan elemen itu menunjukkan jumlah, sedangkan ciriciri tertentu menunjukkan karakteristik dari kumpulan itu (Anwar Sanusi, 2014: 87). Dalam penelitian ini yang dijadikan populasi adalah para tamu yang menginap pada Wisma Syariah Graha Az-Zahra Pekanbaru tahun 2016 berjumlah 3.448 orang.

Sampel adalah bagian dari populasi yang mempunyai ciri-ciri atau keadaan tertentu yang akan diteliti. Karena tidak semua data dan informasi akan diproses dan tidak semua orang atau benda akan diteliti melainkan cukup dengan menggunakan sampel yang mewakilinya (Riduwan, 2014: 10).

Dari jumlah populasi di atas, maka penulis melakukan pengambilan sampel. Adapun jumlah sampel ditentukan berdasarkan rumus Slovin. Setelah dilakukan perhitungan, maka jumlah sampelnya adalah 97 orang. Teknik pengambilan sampel dalam penelitian ini adalah menggunakan simple random sampling, yaitu pengambilan sampel secara acak dimana anggota sampelnya mendapatkan kesempatan yang sama untuk dijadikan sampel (Sanusi, 2014: 101).

Subjek penelitian ini adalah para tamu yang menginap pada Wisma Syariah Graha Az-Zahra PekanbaruRiau. Sedangkan objek penelitian ini adalahpengaruh bauran promosi terhadap peningkatan jumlah tamu pada Wisma Syariah Graha Az-Zahra Pekanbaru Riau.

Sumber data yang digunakan dalam penelitian ini adalah: (a) Data primer adalah data yang diperoleh atau dikumpulkan langsung di lapangan oleh orang yang melakukan penelitian atau yang bersangkutan yang memerlukannya, data primer ini disebut juga data asli atau data baru, yang secara teknis penelitian tersebut responden. Contohnya data dari angket; dan (b) Data sekunder adalah data yang diperoleh atau dikumpulkan oleh orang yang melakukan penelitian dari sumbersumber yang telah ada. Data ini biasanya diperoleh dari perpustakaan atau dari laporan-laporan penelitian terdahulu. Contohnya data yang diberikan oleh pihak Wisma Syariah Graha Az-Zahra kepada penulis (Misbahuddin dan Iqbal Hasan, 2013: 21-22).

Untuk melengkapi data yang diperlukan, ada dua macam teknik pengumpulan data yang digunakan dalam penelitian ini adalah sebagai berikut: (a) Angket. Angket (questionnaire) merupakan suatu daftar pertanyaan atau pernyataan tentang topik tertentu yang diberikan kepada subyek, baik secara individual atau kelompok, untuk mendapatkan informasi tertentu, seperti referensi, keyakinan, minat dan perilaku. Teknik angket ini digunakan dengan cara menyebarkan daftar pertanyaan/ pernyataan kepada para Tamu guna mempermudah di dalam pelaksanaan pengumpulan data (Taniredja dan Mustafidah, 2011: 44); dan (b) Dokumentasi. Dokumentasi adalah ditujukan untuk memperoleh data langsung dari tempat penelitian. Teknik ini digunakan untuk mengumpulkan data tentang sejarah berdirinya perusahaan, visi, misi, keadaan karyawan dan sarana prasarana perusahaan. Data-data yang penulis 
butuhkan dalam mengumpulkan data diantaranya meliputi buku-buku yang relevan, peraturan-peraturan, laporan kegiatan, foto-foto, data yang relevan penelitian (Riduwan, 2014: 58).

Analisis data yang digunakan dalam penelitian ini adalah dengan menggunakan metode deskriptif kuantitatif yaitu menganalisis data secara argumentasi berdasarkan datadata bersifat karakteristik atas jawaban angket yang telah diperoleh dari tamu Wisma Syariah Graha Az-Zahra Pekanbaru dan menganalisis data secara statistik dengan menggunakan analisis regresi linear sederhana yaitu untuk mengukur pengaruh antara variabel $\mathrm{X}$ terhadap variabel $\mathrm{Y}$ dimana proses perhitungannya menggunakan program SPSS Versi 17.0 for Windows.

Uji validitas adalah suatu ukuran yang menunjukkan tingkat kevalidan atau kesahihan suatu instrumen. Suatu instrumen dikatakan valid jika instrumen tersebut mengukur apa yang seharusnya diukur. Cara yang digunakan adalah dengan analisis item dimana setiap nilai yang ada pada setiap butiran pernyataan dikorelasikan dengan total nilai seluruh butir untuk suatu variabel dengan menggunakan rumus korelasi. Syarat minimum untuk dianggap valid $r$ hitung $>$ dari nilai $r$ tabel $(0,2)$. (Sanusi, 2014: 76).

Uji reliabilitas dimaksud untuk mengetahui adanya konsistensi alat ukuran dalam penggunaannya atau dengan kata lain alat ukur tersebut mempunyai hasil konsisten apabila digunakan berkali-kali pada waktu yang berbeda. Untuk uji reliabilitas digunakan teknik Cronbach Alpha dimana suatu instrumen dapat dikatakan handal atau reliabel bila memiliki koefisien kehandalan atau alpha sebesar 0,6 atau lebih (Sanusi, 2014: 80).

Analisis regresi linier sederhana adalah regresi linier sederhana terdiri atas dua variabel. Satu variabel yang berupa variabel terikat/tergantung diberi simbol Y dan variabel kedua yang berupa variabel bebas diberi simbol $\mathrm{X}$. Regresi sederhana ini menyatakan hubungan kausalitas antara dua variabel dan memperkirakan nilai variabel terikat berdasarkan nilai variabel bebas (Sanusi, 2014: 131).

Analisis regresi ini digunakan untuk mengetahui atau mengukur pengaruh antara bauran promosi terhadap peningkatan jumlah tamu yang dinyatakan dalam bentuk persamaan matematik.

Koefisien Korelasi (KK) adalah indeks atau bilangan yang digunakan untuk mengukur derajat hubungan, meliputi kekurangan hubungan dan bentuk/arah hubungan. Fungsi utama dari analisis korelasi adalah untuk menentukan seberapa erat hubungan antara satu variabel dengan variabel lainnya. Ukuran yang menyatakan keeratan hubungan tersebut adalah koefisien korelasi atau sering disebut dengan Korelasi Pearson (Pearson Product Moment). Koefisien korelasi pearson bernilai -1 sampai dengan +1 (Sanusi, 2014: 122).

\section{HASIL \\ Gambaran Umum Wisma Syariah Graha Az-Zahra Pekanbaru}

Menuju sebuah kota

metropolitan, Pekanbaru tidak saja harus dibenahi oleh pemerintah,akan tetapi peran serta masyarakat luas tentu sangat diharapkan dengan memberikan kesempatan kepada strata menengah kebawah untuk bisa menikmati keindahan KotaPekanbaru, inilah konsep awal berdirinya Wisma SyariahGraha Az-Zahra. Maka pada tanggal 01 Agustus tahun 2008 dioperasikanlah Wisma SyariahGraha Az-Zahra dengan berlokasi di jalan Rindang No 16 B, Bukit Raya Pekanbaru, lokasi yang strategis terletak ditengah 
kota kurang lebih sekitar sepuluh menit dari bandara dengan suasana alami seperti diperkampungan yang akan menambah kenyamanan untuk tamu yang memerlukan tempat peristirahatan baik bagi yang sedang melaksanakan bisnis maupun rekreasi.

Awalnya Wisma SyariahGraha AzZahraini hanya membuat 30 kamar saja, karena semakin banyak peminat, maka didirikan lagi fasilitas kamar sebanyak 30 (tiga puluh) kamar,4 (empat) kamar diantaranya adalah VIP Room. Sekarang jumlah kamar sudah berjumlah sebanyak 60 kamar, dengan fasilitas hotel berbintang yang berani memberikan harga promosi kamar dengan tipe serta harga yang terjangkau bagi pelanggan atau tamu.

Wisma Syariah Graha Az-Zahra memegang prinsip-prinsip syariah atau pedoman ajaran Islam, semua karyawan harus taat dan patuh pada peraturan yang berlaku, bagi karyawan yang melanggar akan dikenakan sanksi atau dipecat secara tidak horma. Bagi pelanggan atau tamu yang menginap wajib mengikuti peraturan yang telah ada, khususnya pasangan suami istri agar dapat menunjukan identitas suami istri atau menunjukan surat nikah, di Wisma Syariah Graha Az-Zahra tidak dibenarkan untuk menerima pelanggan atau tamu yang hanya sekedar esekesek.

Dalam manajemen perusahaan,
Wisma Syariah Graha-Az-Zahra Pekanbaru memiliki prinsip yang wajib dipegang teguh oleh tiap karyawan, yaitu: (a) Jujur Terhadap Pelanggan dan Perusahaan; (b) Disiplin Terhadap Waktu dan Pelayanan; (c) Bekerja Sama dan Sama-sama Bekerja; dan (d) Memberikan Pelayanan yang Prima Terhadap Pelanggan

Adapun Departemen-departemen WismaSyariah Graha-Az-Zahra Pekanbaru, yakni: (a) Departemen Pelayanan Tamu (guest service departement), adalah departemen Wisma yang tugasnya berhubungan langsung dengan tamu, menerima reservasi kamar check-in dan check-out tamu, konfirmasi perbedaan kamar, pindah kamar, maupun memberikan informasi yang diinginkan tamu terutama tentang produk Wisma, departemen ini merupakan kesan pertama bagi tamu ketika datang dan melakukan check-in; (b) Departemen Tata Graha (housekeeping departement), adalah departemen Wisma yang bertanggung jawab kebersihan area di wisma baik itu in door maupun out door. Bertanggung jawab atas kebersihan kamar-kamar tamu baik yang occupied maupun yang check-out, serta menyediakan kamar tamu yang siap untuk dijual; (c) Departemen Pelayanan Makanan dan Minuman (food and beverage service departement), adalah departemen Wisma yang bertanggung jawab membuat/menyediakan pelayanan makanan dan minuman yang dipesan oleh tamu sesuai dengan menunya, serta memberikan pelayanan kepada tamu pada saat makan di kantin atau mengganti menunya; (d) Departemen Binatu (laundry departement), adalah departemen Wisma yang bertanggung jawab pencucian linen yang ada di Wisma, koordinasi dan kontrol linen ataupun uniform yang ada di Wisma; (e) Departemen Akunting (accounting departement), adalah departemen Wisma yang bertanggung jawab masalah administrasi Wisma baik pendapatan maupun pengeluaran keuangan di Wisma; (f) Departemen Penjualan dan Pemasaran (sales dan marketing departement), adalah departemen Wisma yang bertugas memasarkan, menjual, mempromosikan serta mengadakan perjanjian kerja sama kepada pihak yang merekomendasikan produk Wisma; dan (g) Departemen Keamanan (security departement), 
adalah departemen Wisma yang bertugas menjaga agar tamu terhindar dari pencurian, perusakan, perampokkan, dan bahaya kebakaran hingga tamu merasa aman menginap di Wisma.

Adapun tipe dan harga kamar Wisma Syariah Graha Az-Zahra Pekanbaru, yakni: (a) Tipe dan harga kamaruntuk tarif harian, terdiri dari : (1) Vip Room, dengan harga Rp. 300.000 pax/day. Fasilitas meliputi: Single bad, Tv LCD, Air Conditioner (AC), Bath-Up, Kamar mandi shower, Kulkas mini, Sopa bed, Telepon, Al-Qur'an dan Sajadah; (2) Cottage Room, terletak di Blok $\mathrm{C}$ dengan harga Rp. 250.000 pax/day. Fasilitas meliputi: Single/Double Bad, Tv 21 Inch, Air Conditioner (AC), Kamar mandi shower, Kulkas mini, Sajadah, Al-qur'an, Telepon dan Kompor Gas + LPG ukuran $15 \mathrm{Kg}$; (c) Deluxe Room, Blok D dan E, Lantai 1 dan 2, dengan harga Rp. 225.000 pax/day. Fasilitas meliputi: Single/Double Bad, Tv 21 Inch, Air Conditioner (AC), Kamar mandi shower, Buth-Up, Sajadah, Al-qur'an, Sopa bed dan Telepon; dan (4) Standart Room, Blok A dan B Lantai 1, 2 dan 3. Dengan harga Rp. 200.000 s/d 185.000 pax/day. Fasilitas meliputi: Single/Double Bed, Tv 21 Inch, Air Conditioner (AC), Kamar mandi shower Buth-Up, Sajadah, Alqur'an, Meja kerja, Telepon dan Lemari Pakaian; dan (b) Tipe dan harga kamar untuk tarif bulanan, terdiri dari: (1) Vip Room, dengan harga Rp. 5.000.000/ bulan ( untuk 2 orang). Fasilitas meliputi: Single bad, Tv LCD, Air Conditioner (AC), Bath-Up, Kamar mandi shower, Kulkas mini, Sofa bed, Sajadah, Al-qur'an dan Telepon; (2) Cottage
Room, Blok C kamar 1C-1 s/d 1C-5. Dengan harga Rp. 3.500.000/ bulan ( untuk 2 orang). Fasilitas meliputi: Single/ Double Bed, Tv 21 Inch, Air Conditioner (AC), Kamar mandi shower, Kulkas mini, Sajadah, Al-qur'an, Telepon dan Kompor Gas + LPG ukuran 15 Kg; (3) Deluxe Room, Blok D dan E lantai 1 dan 2 dengan harga Rp. 3.000.000/ bulan ( untuk 2 orang). Fasilitas meliputi: Single/Double Bed, Tv 21 Inch, Air Conditioner (AC), Kamar mandi shower, Sajadah, Al-qur'an, Sopa Bed dan Telepon; dan (4) Standart Room, Blok A dan B, lantai 1 dengan harga Rp. 2.500.000/ Bulan (untuk 2 orang). Lantai 2 dengan harga Rp. 2.000.000/ Bulan (untuk 2 orang). Dan lantai 3 dengan harga Rp. 1.500.000/ Bulan (untuk 2 orang). Fasilitas meliputi: Single/Double Bed, Tv 21 Inch, Air Conditioner (AC), Kamar mandi shower, Sajadah, Al-qur'an, Meja Kerja, Telepon dan Lemari pakaian.

\section{Deskripsi Bauran Promosi (X)}

Variabel Bauran Promosi dalam penelitian ini yang mana mencakup tentang indikator periklanan (advertising), penjualan personal (personal selling), promosi penjualan (sales promotion), hubungan masyarakat (public relations), informasi dari mulut ke mulut (word of mounth), pemasaran langsung (direct marketing) dan pemasaran melalui internet (internet marketing).

Dari tanggapan responden terhadap masing-masing indikator variabel bauran promosi, maka dapat dibuat rekapitulasi sebagai berikut:

Tabel 2: Rekapitulasi Tanggapan Responden Terhadap Variabel Bauran Promosi Pada Wisma Syariah Graha Az-Zahra Pekanbaru

\begin{tabular}{cccccccc}
\hline & & \multicolumn{7}{c}{ Rekapitulasi Perhitungan Data Angket } \\
\cline { 3 - 8 } No & Pernyataan & SS & S & N & TS & STS & Jumlah \\
\hline 1 & 1 & 21 & 45 & 21 & 0 & 0 & 97 \\
\hline
\end{tabular}




\begin{tabular}{lccccccc}
\hline 2 & 2 & 35 & 41 & 21 & 0 & 0 & 97 \\
\hline 3 & 3 & 37 & 48 & 12 & 0 & 0 & 97 \\
\hline 4 & 4 & 39 & 46 & 12 & 0 & 0 & 97 \\
\hline 5 & 5 & 38 & 45 & 14 & 0 & 0 & 97 \\
\hline 6 & 6 & 35 & 50 & 12 & 0 & 0 & 97 \\
\hline 7 & 7 & 31 & 48 & 18 & 0 & 0 & 97 \\
\hline 8 & 8 & 31 & 47 & 19 & 0 & 0 & 97 \\
\hline 9 & 9 & 29 & 48 & 17 & 3 & 0 & 97 \\
\hline 10 & 10 & 32 & 41 & 19 & 5 & 0 & 97 \\
\hline 11 & 11 & 31 & 48 & 14 & 4 & 0 & 97 \\
\hline 12 & 12 & 36 & 39 & 22 & 0 & 0 & 97 \\
\hline 13 & 13 & 35 & 38 & 22 & 2 & 0 & 97 \\
\hline 14 & 14 & 30 & 48 & 15 & 4 & 0 & 97 \\
\hline 15 & 15 & 29 & 44 & 21 & 3 & 0 & 97 \\
\hline 16 & 16 & 29 & 43 & 23 & 2 & 0 & 97 \\
\hline 17 & 17 & 27 & 47 & 21 & 2 & 0 & 97 \\
\hline 18 & 18 & 30 & 46 & 21 & 0 & 0 & 97 \\
\hline 19 & 19 & 32 & 47 & 18 & 0 & 0 & 97 \\
\hline Jumlah & & $\mathbf{6 0 7}$ & $\mathbf{8 5 9}$ & $\mathbf{3 4 2}$ & $\mathbf{2 6}$ & $\mathbf{0}$ & $\mathbf{1 . 8 4 3}$ \\
\hline $\begin{array}{l}\text { Nilai Skor } \\
\text { Total Skor }\end{array}$ & $\mathbf{5}$ & $\mathbf{4}$ & $\mathbf{3}$ & $\mathbf{2}$ & $\mathbf{1}$ & \\
\hline $\begin{array}{l}\text { GrandTotal Skor } \\
\text { Rata-rata }\end{array}$ & Skor & $\mathbf{3 . 0 3 5}$ & $\mathbf{3 . 4 3 6}$ & $\mathbf{1 . 0 2 6}$ & $\mathbf{5 2}$ & $\mathbf{0}$ & \\
$\begin{array}{l}\text { Penelitian } \\
\text { Persentase }\end{array}$ & & & & & & & $\mathbf{7 . 5 4 9}$ \\
\hline
\end{tabular}

Berdasarkan hasil rekapitulasi jawaban responden pada tabel 2 di atas dapat dilihat bahwa rekapitulasi bauran promosi (X) nilai tertinggi menyatakan setuju dengan besaran nilai $46,6 \%$, selanjutnya sangat setuju dengan persentase $33,4 \%$, netral dengan persentase $18,6 \%$, selanjutnya tidak setuju dengan persentase 1,4\%, sedangkan sangat tidak setuju dengan persentase $0,00 \%$ dengan butir-butir pernyataan dari variabel X yaitu 19 butir. Berdasarkan tabel di atas dapat dinyatakan bahwa bauran promosi yang diaplikasikan Wisma Syariah Graha Az-
Zahra Pekanbaru sudah diaplikasikan dengan baik dalam rangka meningkatkan jumlah tamu.

\section{Deskripsi Peningkatan Jumlah Tamu (Y)}

Variabel peningkatan jumlah tamu dalam penelitian ini yang mana mencakup tentang indikator hunian kamar (room occupancy), dan loyalitas pelanggan (customer loyalty).

Dari tanggapan responden terhadap masing-masing indikator variabel peningkatan jumlah tamu, maka dapat dibuat rekapitulasi sebagai berikut:

Tabel 3: Rekapitulasi Tanggapan Responden Terhadap Variabel Peningkatan Jumlah Tamu Pada Wisma Syariah Graha Az-Zahra Pekanbaru

\begin{tabular}{|c|c|c|c|c|c|c|c|}
\hline \multirow[b]{2}{*}{ No. } & \multirow[b]{2}{*}{ Pernyataan } & \multicolumn{6}{|c|}{ Rekapitulasi Perhitungan Data Angket } \\
\hline & & SS & $S$ & $\mathbf{N}$ & TS & STS & Jumlah \\
\hline 1 & 1 & 34 & 41 & 19 & 3 & 0 & 97 \\
\hline 2 & 2 & 33 & 48 & 12 & 4 & 0 & 97 \\
\hline \multicolumn{2}{|c|}{ Jumlah } & 67 & 89 & 31 & 7 & $\mathbf{0}$ & 194 \\
\hline \multicolumn{2}{|c|}{ Nilai Skor } & 5 & 4 & 3 & 2 & 1 & \\
\hline \multicolumn{2}{|c|}{ Total Skor } & 335 & 356 & 93 & 14 & $\mathbf{0}$ & \\
\hline \multicolumn{2}{|c|}{ Grand Total Skor } & & & & & & 798 \\
\hline \multicolumn{2}{|c|}{$\begin{array}{l}\text { Rata-rata } \\
\text { Penelitian }\end{array}$} & & & & & & 399 \\
\hline
\end{tabular}




\begin{tabular}{llllll}
\hline Persentase & $34,5 \%$ & $45,8 \%$ & $15,9 \%$ & $3,6 \%$ & $0 \%$ \\
\hline
\end{tabular}

Berdasarkan hasil rekapitulasi jawaban responden pada tabel 3 di atas dapat dilihat bahwa rekapitulasi peningkatan jumlah tamu (Y) nilai tertinggi mengatakan setuju dengan besaran nilai $45,8 \%$, selanjutnya sangat setuju dengan persentase $34,5 \%$, netral dengan persentase $15,9 \%$, selanjutnya tidak setuju dengan persentase $3,6 \%$, sedangkan sangat tidak setuju dengan persentase $0,00 \%$ dengan butir-butir pernyataan dari variabel Y yaitu 2 butir. Berdasarkan tabel di atas dapat dinyatakan bahwa jumlah tamu meningkat secara signifikan karena
Wisma Syariah Graha Az-Zahra Pekanbaru sudah mengaplikasikan bauran promosi dengan baik.

Dari hasil penelitian terhadap indikator setiap variabel dalam penelitian ini semuanya valid. Indikator setiap variabel signifikan terhadap topik yang diteliti. Berikut hasil dari pengujian validitas untuk item-item variabel pengaruh bauran promosi terhadap peningkatan jumlah tamu pada Wisma Syariah Graha Az-Zahra Pekanbaru.

Berikut ini dilihatkan tabel tentang hasil uji validitas dan butir-butir pernyataan responden penelitian:

Tabel 4: Hasil Uji Validitas

\begin{tabular}{|c|c|c|c|c|}
\hline Variabel & $\begin{array}{c}\text { Item } \\
\text { Pernyataan }\end{array}$ & $\begin{array}{l}\text { Corrected item- } \\
\text { total correlation } \\
\text { (r hitung) }\end{array}$ & $\begin{array}{c}r \text { tabel } \\
(\alpha=0,05)\end{array}$ & Keterangan Hasil \\
\hline \multirow[t]{19}{*}{$\mathrm{X}$} & Item 1 & 0,842 & 0,202 & Valid \\
\hline & Item 2 & 0,841 & 0,202 & Valid \\
\hline & Item 3 & 0,859 & 0,202 & Valid \\
\hline & Item 4 & 0,875 & 0,202 & Valid \\
\hline & Item 5 & 0,847 & 0,202 & Valid \\
\hline & Item 6 & 0,806 & 0,202 & Valid \\
\hline & Item 7 & 0,763 & 0,202 & Valid \\
\hline & Item 8 & 0,776 & 0,202 & Valid \\
\hline & Item 9 & 0,793 & 0,202 & Valid \\
\hline & Item 10 & 0,747 & 0,202 & Valid \\
\hline & Item 11 & 0,741 & 0,202 & Valid \\
\hline & Item 12 & 0,791 & 0,202 & Valid \\
\hline & Item 13 & 0,829 & 0,202 & Valid \\
\hline & Item 14 & 0,759 & 0,202 & Valid \\
\hline & Item 15 & 0,832 & 0,202 & Valid \\
\hline & Item 16 & 0,862 & 0,202 & Valid \\
\hline & Item 17 & 0,845 & 0,202 & Valid \\
\hline & Item 18 & 0,861 & 0,202 & Valid \\
\hline & Item 19 & 0,853 & 0,202 & Valid \\
\hline \multirow[t]{2}{*}{$\mathrm{Y}$} & Item 20 & 0,956 & 0,202 & Valid \\
\hline & Item 21 & 0,950 & 0,202 & Valid \\
\hline
\end{tabular}

Sumber: Data Olahan SPSS Versi 17.0, 2017.

Dari tabel 4 di atas dapat dilihat bahwa semua indikator variabel dapat dikatakan valid karena, jika $r_{\text {hitung }}>r_{\text {tabel }}$ maka item-item pernyataan dinyatakan valid.

Diketahui nilai $r_{\text {tabel }}$ dengan taraf signifikan 5\% $(\alpha=0,05)$, adalah sebesar
0,202 (lihat tabel $r$ ) dan nilai ini dibandingkan dengan nilai $r_{\text {hitung }}$. Nilai $r_{\text {hitung dalam uji validitas ini adalah }}$ pada kolom Item-Total statistic (Corrected Item-Total). Dan dari tabel di atas menunjukkan bahwa butir pernyataan tersebut dinyatakan valid. 
Selanjutnya, batasan nilai dalam uji reliabilitas adalah 0,6. Jika nilai reliabilitas kurang dari 0,6 maka nilainya kurang baik. Nilai reliabilitas dalam uji ini adalah pada kolom Reliability Statistic (Cronbach's Alpha).

Berikut ini akan dilihatkan tabel tentang hasil uji validitas dari butirbutir pernyataan responden penelitian:

Tabel 5: Hasil Uji Reliabilitas

\begin{tabular}{|c|c|c|c|}
\hline Variabel & Item Pernyataan & Cronbach's Alpha & Keterangan Hasil \\
\hline \multirow[t]{19}{*}{$\mathrm{X}$} & Item 1 & 0,729 & Reliabel \\
\hline & Item 2 & 0,750 & Reliabel \\
\hline & Item 3 & 0,666 & Reliabel \\
\hline & Item 4 & 0,673 & Reliabel \\
\hline & Item 5 & 0,693 & Reliabel \\
\hline & Item 6 & 0,658 & Reliabel \\
\hline & Item 7 & 0,702 & Reliabel \\
\hline & Item 8 & 0,711 & Reliabel \\
\hline & Item 9 & 0,751 & Reliabel \\
\hline & Item 10 & 0,794 & Reliabel \\
\hline & Item 11 & 0,741 & Reliabel \\
\hline & Item 12 & 0,759 & Reliabel \\
\hline & Item 13 & 0,818 & Reliabel \\
\hline & Item 15 & 0,794 & Reliabel \\
\hline & Item 15 & 0,782 & Reliabel \\
\hline & Item 16 & 0,790 & Reliabel \\
\hline & Item 17 & 0,741 & Reliabel \\
\hline & Item 18 & 0,723 & Reliabel \\
\hline & Item 19 & 0,707 & Reliabel \\
\hline \multirow[t]{2}{*}{$\mathrm{Y}$} & Item 20 & 0,794 & Reliabel \\
\hline & Item 21 & 0,741 & Reliabel \\
\hline
\end{tabular}

Sumber: Data Olahan SPSS Versi 17.0, 2017.

Berdasarkan uji reliabilitas dengan menggunakan Cronbach's Alphadari tabel 5 di atas maka dapat disimpulkan bahwa 21 butir pernyataan tentang pengaruh bauran promosi terhadap peningkatan jumlah tamu pada Wisma Syaraiah Graha Az-Zahra Pekanbaru dapat dinyatakan reliabel.
Hasil perhitungan analisis regresi sederhana melalui SPSS For Windows Versi 17.0, maka dapat diperoleh nilai untuk variabel bebas dan variabel terikat dapat dilihat pada tabel dibawah ini:

Tabel 6: Hasil Uji Analisis Regresi Sederhana

\begin{tabular}{llrrrrr}
\hline & \multicolumn{2}{c}{ Unstandardized Coefficients } & \multicolumn{2}{c}{ Standardized Coefficients } & & \\
\cline { 2 - 7 } Model & B & Std. Error & Beta & \multicolumn{1}{c}{ T } & \multicolumn{1}{c}{ Sig. } \\
\hline 1 & (Constant) & 28.183 & 4.203 & & 6.705 & .000 \\
\cline { 2 - 7 } & $\begin{array}{l}\text { Bauran } \\
\text { Promosi }\end{array}$ & 6.089 & .500 & .781 & 12.17 & .000 \\
& & & 6 & & \\
\hline
\end{tabular}

Bentuk umum dari persamaan regresi dinyatakan dengan persamaan matematika, yaitu:

$\hat{Y}=a+b X$
$\hat{Y}=28,183+6,089 X$

Arti dari angka-angka dalam persamaan regresi di atas adalah: (1) Nilai a sebesar 28,183 mengindikasikan 
bahwa apabila tidak dilakukan promosi atau nilai $\mathrm{X}=0$, maka nilai variabel $\mathrm{Y}$ sebesar 28,183; dan (2) Nilai b sebesar 6,089 mengindikasikan bahwa apabila nilai variabel bauran promosi (X) meningkat maka variabel peningkatan jumlah tamu (Y) akan mengalami peningkatan sebesar 6,089 satuan dengan asumsi bahwa variabel $\mathrm{X}$ tetap atau konsisten.

Uji- $t$ dilakukan untuk melihat pengaruh variabel, yaitu varibel bebas dan variabel terikat dengan menggunakan Uji-t (Uji Parsial) dengan bantuan komputer program SPSS For Windows Versi 17.0, maka hasil Uji-t dapat dilihat pada tabel di bawah ini:

Tabel 7: Hasil Perhitungan Uji-t

\begin{tabular}{|c|c|c|c|c|c|c|}
\hline \multirow{2}{*}{\multicolumn{2}{|c|}{ Model }} & \multicolumn{2}{|c|}{ Unstandardized Coefficients } & \multirow{2}{*}{$\begin{array}{c}\text { Standardized Coefficients } \\
\text { Beta }\end{array}$} & \multirow[b]{2}{*}{$\mathrm{T}$} & \multirow[b]{2}{*}{ Sig. } \\
\hline & & B & Std. Error & & & \\
\hline \multirow[t]{2}{*}{1} & (Constant) & 28.183 & 4.203 & & 6.705 & .000 \\
\hline & $\begin{array}{l}\text { Bauran } \\
\text { Promosi }\end{array}$ & 6.089 & .500 & .781 & 12.176 & .000 \\
\hline
\end{tabular}

Sumber: Data Olahan SPSS Versi 17.0.

Dari pengolahan tabel 7 di atas dapat diketahui bahwa nilai t hitung variabel bauran promosi (X) sebesar 12,176 dan nilai $t_{\text {tabel }}$ sebesar 1,980 dengan tingkat signifikan sebesar 0,05 dan derajat kebebasan sebesar $96\{(\mathrm{dk}=\mathrm{n}-1)(97-1)\}$ maka terlihat bahwa $t_{\text {hitung }}>t_{\text {tabel }}$ atau 12,176 > 1,980. Hal ini menunjukkan bahwa Ho ditolak dan Ha diterima, sehingga dapat dikatakan bahwa terdapat pengaruh yang signifikan antara bauran promosi terhadap peningkatan jumlah tamu.

Dari penjelasan di atas maka secara parsial dapat dikatakan bahwa bauran promosi sangat mempengaruhi peningkatan jumlah tamu pada Wisma Syariah Graha AzZahra Pekanbaru dengan hasil nilai sebesar 12,176.

Koefisien korelasi berfungsi untuk melihat kuat lemahnya pengaruh antara variabel bebas terhadap variabel terikat. Untuk mengetahui hal tersebut, maka dapat digunakan koefisien korelasi dengan menggunakan bantuan komputer dengan program SPSS For Windows Versi 17.0, dan hasil pengolahan dapat dilihat pada tabel di bawah ini:

Tabel 8: Analisis Korelasi

\begin{tabular}{crrrr} 
Model & $\mathrm{R}$ & $R$ Square & Adjusted $R$ Square & Std. Error of the Estimate \\
\hline 1 & $.781^{\mathrm{a}}$ & .609 & .605 & 7.168 \\
\hline
\end{tabular}

Dari pengolahan tabel 8 di atas dapat diketahui bahwa nilai $R$ menunjukkan korelasi antara variabel independen dengan variabel devenden. Di sini diketahui nilai $R$ sebesar 0,781 atau $78,1 \%$. Artinya bahwa korelasi antara variabel bauran promosi dengan variabel peningkatan jumlah tamu memiliki hubungan yang kuat.

Kemudian untuk melihat besarnya nilai kontribusi variabel $\mathrm{X}$ terhadap variabel $Y$ digunakan uji koefisien 
determinasi. Koefisien determinasi adalah untuk menunjukkan seberapa besar perubahan variabel terikat (Y) yang dapat dipengaruhi oleh variabel bebas (X).

Dari pengolahan data di ketahui nilai $R$ Square sebesar 0,609. Artinya adalah bahwa kontribusi pengaruh variabel independen (X) terhadap varaibel dependen (Y) adalah sebesar $60,9 \%$, sedangkan sisanya adalah $39,1 \%$ dipengaruhi oleh variabel lain yaitu product (produk), price (harga), place (tempat), people (orang), process (proses), physical evidence (bukti fisik) yang tidak dimasukkan dalam penelitian ini.

\section{PEMBAHASAN}

Penelitian yang telah penulis lakukan tentang pengaruh bauran promosi terhadap peningkatan jumlah tamu pada Wisma Syariah Graha AzZahra Pekanbaru terdiri dari dua variabel yaitu variabel bebas (bauran promosi) dan variabel terikat (peningkatan jumlah tamu).

Adapun jenis penelitian yang penulis gunakan dalam penelitian ini adalah penelitian kausalitas untuk meneliti kemungkinan adanya hubungan sebab-akibat antara variabel bebas (bauran promosi) terhadap variabel terikat (peningkatan jumlah tamu).

Analisis data yang digunakan dalam penelitian ini adalah metode kualitatif dan kuantitatif. Metode kualitatif yaitu menganalisis data secara argumentasi berdasarkan data-data bersifat karakteristik atas jawaban angket yang telah disebarkan penulis, dan metode kuantitatif yaitu menganalisis data secara statistik dengan menggunakan analisis regresi sederhana yaitu mengukur pengaruh antara variabel bebas (X) terhadap variabel terikat (Y) dan proses perhitungan datanya dengan menggunakan komputer program SPSS Versi 17.0 For Windows.

Untuk mendapatkan hasil analisis di atas langkah yang pertama, penulis melakukan dari hasil penelitian mengenai tanggapan responden menilai bauran promosi yang dilakukan oleh Wisma Syariah Graha Az-Zahra Pekanbaru, diketahui bahwa sebesar $46,6 \%$ responden memberikan tanggapan setuju untuk menilai terhadap bauran promosi yang telah dilakukan oleh Wisma Syariah Graha AzZahra Pekanbaru. Selanjutnya tanggapan responden menilai peningkatan jumlah tamu yang terjadi di Wisma Syariah Graha Az-Zahra Pekanbaru, diketahui bahwa sebesar $45,8 \%$ responden memberikan tanggapan setuju untuk menilai terhadap peningkatan jumlah tamu di Wisma Syariah Graha Az-Zahra Pekanbaru.

Kemudian langkah kedua, penulis melakukan pengujian signifikan atau uji parsial antara bauran promosi terhadap peningkatan jumlah tamu, pengujian ini dilakukan untuk mengetahui pengaruh bauran promosi terhadap peningkatan jumlah tamu pada Wisma Syariah Graha Az-Zahra Pekanbaru. Dari hasil pengujian tersebut dapat diketahui terdapat pengaruh yang signifikan antara pengaruh bauran promosi terhadap peningkatan jumlah tamu pada Wisma Syariah Graha Az-Zahra Pekanbaru, ini diketahui nilai $t_{\text {hitung }}(12,176)$ lebih besar dari nilai $t_{\text {tabel }}(1,980)$. Berarti secara parsial dapat diketahui bahwa variabel $\mathrm{X}$ (Bauran Promosi) berpengaruh terhadap variabel Y (Peningkatan Jumlah Tamu).

Selanjutnya penulis melakukan pengujian koefisien korelasi, dimana fungsi utama koefisien korelasi untuk menentukan seberapa erat korelasi (hubungan) antara bauran promosi 
terhadap peningkatan jumlah tamu. Berdasarkan hasil perhitungan di atas diketahui bahwa besarnya koefisien korelasi bauran promosi terhadap peningkatan jumlah tamu dengan ditunjukkan nilai $(R)$ sebesar 78,1\%. Ini merupakan hubungan antara bauran promosi terhadap peningkatan jumlah tamu pada Wisma Syariah Graha AzZahra Pekanbaru termasuk dalam kategori hubungan yang kuat.

Terakhir yang dilakukan oleh penulis adalah analisis koefisien determinasi, dimana koefisien determinasi merupakan besaran yang menunjukkan seberapa besar kontribusi pengaruh variabel X (Bauran Promosi) terhadap variabel $Y$ (Peningkatan Jumlah Tamu). Dari hasil analisis diketahui bahwa besarnya nilai kontribusi antara bauran promosi terhadap peningkatan jumlah tamu dengan ditunjukkan nilai $R$ Square sebesar $60,9 \%$ dan sisanya 39,1\% dipengaruhi oleh faktor lain yaitu product (produk), price (harga), place (tempat), people (orang), process (proses), physical evidence (bukti fisik) yang tidak dimasukkan dalam penelitian ini.

\section{SIMPULAN}

Berdasarkan dari hasil penelitian yang membahas tentang pengaruh bauran promosi terhadap peningkatan jumlah tamu pada Wisma Syariah Graha Az-Zahra Pekanbaru maka penulis dapat menyusun beberapa kesimpulan, yakni hasil penelitian mengenai tanggapan responden menilai setuju mengenai bauran promosi yang telah dilakukan oleh Wisma Syariah Graha Az-Zahra Pekanbaru. Tanggapan setuju ini dilihat dari bauran promosi yang dilakukan seperti: periklanan, penjualan perseorangan, promosi penjualan, hubungan masyarakat, pemasaran langsung, informasi dari mulut ke mulut dan pemasaran melalui internet.

Selanjutnya, hasil uji parsial diketahui bahwa terdapat pengaruh yang signifikan antara bauran promosi terhadap peningkatan jumlah tamu pada Wisma Syariah Graha Az-Zahra Pekanbaru.

Sedangkan pada hasil koefisien korelasi menyatakan adanya hubungan yang kuat antara bauran promosi terhadap peningkatan jumlah tamu pada Wisma Syariah Graha Az-Zahra Pekanbaru.

Selain itu, berdasarkan hasil koefisien determinasi menunjukkan bahwa terdapat besarnya nilai kontribusi antara bauran promosi terhadap peningkatan jumlah tamu pada Wisma Syariah Graha Az-Zahra Pekanbaru.

\section{DAFTAR RUJUKAN}

Adam, Muhammad. 2015. Manajemen Pemasaran Jasa. Bandung: Alfabeta.

Al-Arif, Nur Rianto. 2015. Asuransi Syariah. Bekasi: Gramata Publishing.

Alma, Buchari. 2011. Manajemen Pemasaran dan Pemasaran Jasa. Bandung: Alfabeta.

Assauri, Sofjan. 2016. Strategic Manajemen. Jakarta: PT. Raja Grafindo Persada.

Departemen Agama. 2014. Al-Qur'an dan Terjemahannya. Bandung: AlMizan Publishing House.

Departemen Pendidikan Nasional. 2008. Kamus Besar Bahasa Indonesia Pusat Bahasa (KBBI). Jakarta: PT.Gramedia Pustaka Utama.

Hasan, Misbahuddin Iqbal. 2013. Analisis Data Penelitian Dengan Statistik. Jakarta: Bumi Aksara.

Hermawan, Agus. 2012. Komunikasi Pemasaran. Jakarta: Erlangga. 
Kartajaya, Hermawan dan Sula, Muhammad Syakir. 2008. Syariah marketing. Jakarta: PT. Mizan Pustaka.

Manap, Abdul. 2016. Revolusi Manajemen Pemasaran. Jakarta: Mitra Wacana Media.

Mardani, Suhendi. Ayat-ayat dan Hadis Ekonomi Syariah. Jakarta: Rajawali Pers.

Pratomo, Dani Rahadian Adithya. "Pengaruh Bauran Promosi Terhadap PeningkatanPenjualan Kamar Di Hotel Benua Bandung", Skripsi, Jurusan Manajemen Hotel. Skripsi. Fakultas Ekonomi dan Komunikasi, Universitas BINUS, Jakarta Barat, 2013.

Rangkuti, Freddy. 2009. Strategi Promosi Yang Kreatif. Jakarta: Gramedia Pustaka Utama.

Riduwan. 2014. Dasar-dasar Statiska. Bandung: Alfabeta.

Sanusi, Anwar. 2014. Metodologi Penelitian Bisnis. Jakarta: Salemba Empat.
Setiyaningrum, Ari. et Al., 2015. Prinsipprinsip Pemasaran. Yogyakarta: CV. Andi.

Suhendi, Hendi. 2007. Fiqh Muamalah. Jakarta: PT. Raja Grafindo Persada.

Sunyoto, Danang. 2012. Konsep Dasar Riset Pemasaran dan Perilaku Konsumen. Jakarta: PT. Buku Seru.

Tanireja, Tukiran dan Mustafidah, Hidayati. 2011. Penelitian Kuantitatif. Bandung: Alfabeta.

Tjiptono, Fandy dan Chandra, Gregorius. 2011. Service Quality dan Statisfaction. Yogyakarta: CV. Andi.

Suyanto. 2008. Muhammad Business Strategy dan Ethics. Yogyakarta: CV. Andi.

Wardhani, Dewi Kusuma "Pengaruh Jasa Hotel Rauda Terhadap Keputusan Tamu Menginap Pada Hotel Rauda Pekanbaru",Skripsi, Jurusan Manajemen, Fakultas Ekonomi, Universitas Islam Riau (UIR), Pekanbaru, 2016.

Yoeti, Oka A., 2007. Hotel Marketing. Jakarta: PT. Perca. 